\title{
PENGARUH GAYA MENGAJAR GURU DALAM PEMBELAJARAN \\ PENDIDIKAN AGAMA ISLAM TERHADAP MOTIVASI BELAJAR \\ SISWA SEKOLAH MENENGAH ATAS (SMA) NEGERI 4 KOTA \\ CIREBON
}

\author{
Danar Rajak, Nurwahdan, Iwan \\ Fakultas Ilmu Tarbiyah dan Keguruan \\ Institut Agama Islam Negeri Syekh Nurjati Cirebon \\ Email: danarrajak03@gmail.com
}

\begin{abstract}
ABSTRAK
Penelitian ini bermula dari permasalahan, bahwa gaya mengajar guru Pendidikan Agama Islam (PAI) di Sekolah Menengah Atas (SMA) Negeri 4 Kota Cirebon sudah baik, akan tetapi masih ada beberapa siswa kelas XII yang motivasi belajarnya rendah.

Penelitian ini bertujuan memperoleh data tentang gaya mengajar guru Pendidikan Agama Islam di kelas XII Sekolah Mengah Atas (SMA) Negeri 4 Kota Cirebon, memperoleh data tentang motivasi belajar mata pelajaran Pendidikan Agama Islam (PAI) siswa kelas XII Sekolah Menengah Atas (SMA) Negeri 4 Kota Cirebon, memperoleh data tentang pengaruh gaya mengajar guru terhadap motivasi belajar mata pelajaran Pendidikan Agama Islam siswa kelas XII Sekolah Menengah Atas (SMA) Negeri 4 Kota Cirebon

Gaya mengajar guru yang dilakukan dalam setiap proses pembelajaran akan menjadi perhatian siswanya dan menjadikan ciri atau karakter guru tersebut. Seperti guru yang sering melibatkan siswa dalam proses pembelajaran, sehingga peran guru dan siswa sama-sama dominan, guru yang menciptakan pembelajaran yang bersifat dialogis akan berakibat pada motivasi belajar siswa yang dapat diindikasikan dengan sikap siswa yang bergairah, inisiatif, responsif, kesegeraan, konsentrasi, ketelitian, kemauan dan kerja keras dalam mengikuti proses pembelajaran.
\end{abstract}


Penelitian ini menggunakan metode penelitian kuantitatif.Teknik pengumpulan data menggunakan angket.Populasi yang digunakan yaitu seluruh siswa Sekolah Menengah Atas (SMA) Negeri 4 Kota Cirebon yang berjumlah 346.Teknik pengambilan sampel menggunakan simple random sampling dengan jumlah sampel 177. Pengujian hipotesis menggunakan korelasi Person Product Moment (PPM).

Hasil penelitian yang diperoleh bahwa Gaya mengajar guru Pendidikan Agama Islam (PAI) di Sekolah Menengah Atas (SMA) Negeri 4 Kota Cirebon, Berdasarkan hasil perhitungan, maka dapat disimpulkan bahwa gaya mengajar guru Pendidikan Agama Islam (PAI) di Sekolah Menengah Atas (SMA) Negeri 4 Kota Cirebon lebih dominan menggunakan gaya mengajar guru teknologis dengan perolehan rata - rata 80,18\%. Motivasi belajar pada mata pelajaran Pendidikan Agama Islam (PAI) siswa kelas XII Sekolah Menengah Atas (SMA) Negeri 4 Kota Cirebon, Berdasarkan hasil perhitungan, maka dapat disimpulkan bahwa motivasi belajar siswa kelas XII Sekolah Menengah Atas (SMA) Negeri 4 kota Cirebon dalam keadaan baik dengan rata-rata 70,44\%.Berdasarkan nilai signifikansi : dari tabel Coefficients di peroleh nilai signifikansi sebesar 0,000<0,05, sehingga dapat disimpulkan bahwa variabel gaya mengajar guru (X) berpengaruh terhadap variabel motivasi belajar siswa (Y). Adapun pengaruh variabel bebas (Gaya Mengajar Guru) terhadap Variabel terikat (Motivasi Belajar Siswa) adalah sebesar 19,8\% 


\section{PENDAHULUAN}

\section{A. Latar Belakang Masalah}

Mengajar pada intinya mengantarkan siswa untuk mencapai tujuan yang sudah direncanakan sebelumnya. Dalam hal mengajar, guru banyak ragam perilaku yang ditampilkan ketika mengajar, walaupun dengan maksud dan tujuan yang sama. Banyaknya ragam perilaku mengajar Guru, Dianne Lapp dan Kawan - kawan mengistilahkan Ragam mengajar dengan Istilah Gaya Mengajar atau Teaching Style. (Lap dkk.,1975). Aneka Ragam mengajar bisa ditelusuri dan akan memperoleh pola dasar yang akan dijadikan sebagai pedoman untuk mengkaji berbagai gaya mengajar. Pola dasar ragam mengajar yaitu Interaksi antara Guru, Isi dan Murid. Berangkat dari pola dasar itu maka akan diketahui adakalanya guru mendominasi pembelajaran, adakalanya isi mendominasi pembelajaran, adakalanya siswa mendominasi Pembelajaran dan adakalanya guru dan siswa secara seimbang mendominasi pembelajaran (Sumiati dan Asra, 2009: 74).

Sebagaimana, Muhammad Ali (2010: 59-61), Menjelaskan empat macam gaya mengajar, Sebagai berikut :

1. Gaya Mengajar Klasik

Proses pengajaran dengan gaya klasik berusaha untuk memelihara dan menyampaikan nilai-nilai lama dari generasi sebelumnya ke generasi berikutnya, contoh yang dimaksud dengan nilai - nilai lama ialah siswa diberikan didikan dengan budaya yang dianggap benar dan sahih (valid). Isi pelajaran berupa sejumlah informasi dan ide yang paling popular dan dipilih dari dunia yang diketahui anak, sehingga Isi pelajaran banyak mengenai dasar pembentukan intelek dan komunikasi dengan dunia luar.Oleh karenanya, isi pelajaran bersifat objektif, jelas, dan diorganisasi secara sistematis-logis. Proses penyampaian bahan tidak didasarkan atas minat anak, melainkan pada urutan tertentu. Peranan guru di sini lebih dominan dari pada siswa, karena guru harus menyampaikan bahan.oleh karenanya guru harus ahli (expert) tentang pelajaran yang dipegangnya. Sehingga proses pengajaran bersifat pasif, yakni siswa hanya menerima bahan pelajaran.

2. Gaya Mengajar Teknologis 
Pola interaksi Gaya Mengajar Teknologis adalah antara guru, isi dan siswa, yang lebih dominan adalah isi dari bahan pembelajaran itu sendiri.Fokus gaya mengajar ini pada kompetensi siswa secara individual. Bahan pelajaran disesuaikan dengan tingkat kesiapan anak.Peranan isi pelajaran adalah dominan.Oleh karena itu, bahan disusun oleh ahlinya masing-masing.Bahan itu bertalian dengan data objektif dan keterampilan yang dapat menuntun kompetensi vokasional siswa.Peranan siswa di sini adalah belajar dengan menggunakan perangkat atau media. Dengan hanya merespons apa yang diajukan kepadanya melalui perangkat itu, siswa dapat mempelajari apa yang dapat bermanfaat bagi dirinya dalam kehidupan. Peranan guru hanya sebagai pemandu (guide), pengarah (director), atau pemberi kemudahan (facilitator) dalam belajar karena pelajaran sudah diprogram sedemikian rupa dalam perangkat, baik lunak (software) maupun keras (hardware).

3. Gaya Mengajar Personalisasi

Gaya mengajar guru menjadi salah satu kunci keberhasilan siswa. Pada dasarnya guru mengajar bukan untuk memandaikan siswa semata, akan tetapi juga memandaikan pada dirinya. Guru yang mempunyai prinsip seperti ini, ia akan selalu meningkatkan belajarnya dan juga memandang anak didiknya seperti dirinya sendiri. Guru tidak bisa memaksa peserta didiknya untuk menjadi sama dengan gurunya, karena ia mempunyai minat, bakat dan kecenderungan masing-masing. pengajaran personalisasi dilakukan berdasarkan atas minat, pengalaman, dan pola perkembangan mental siswa. Hal ini karena setiap siswa mempunyai minat, bakat, dan kecenderungan masing-masing yang tidak dapat dipaksakan oleh guru.Siswa harus dipandang sebagai seorang pribadi yang mempunyai potensi untuk dikembangkannya.Oleh karena itu, peran guru sangat dibutuhkan untuk memposisikan dirinya sebagai mitra belajar siswa dengan memberikan bantuan atas perkembangan siswa dalam berbagai aspek.

4. Gaya Mengajar Interaksional 
Kehidupan siswa disamping sebagai makhluk individu juga makhluk sosial. Sebagai makhluk sosial, ia hendaknya melakukan interaksi sosial dengan berbagai problematika yang harus dihadapi. Siswa dihadapkan pada suatu realitas yang beraneka ragam. Oleh karenanya, dalam pembelajaran ia diberi kesempatan luas untuk memilih program studi yang sesuai dengan program studi yang sesuai dengan masyarakat kekinian. Siswa juga dilibatkan dalam pembentukan interaksi sosial yang mengharuskan ia mampu belajar secara mandiri.

Peranan guru dan siswa di sini sama-sama dominan. Guru dan siswa berupaya untuk memodifikasi berbagai ide atau ilmu pengetahuan yang dipelajari untuk mencari bentuk baru berdasarkan kajian yang bersifat radikal. Guru dalam hal ini menciptakan iklim saling ketergantungan dan timbulnya dialog antar siswa. siswa belajar melalui hubungan dialogis. Dia mengemukakan pandangannya tentang realita, juga mendengarkan pandangan siswa lain. Dengan demikian dapat ditemukan pandangan baru hasil pertukaran pikiran tentang apa yang dipelajari. Adapun isi pelajaran difokuskan kepada masalah-masalah yang berkenaan dengan sosio-kultural terutama yang bersifat kontemporer. Adapun pengaruh dari Gaya Mengajar Guru salah satunya untuk meningkatkan Motivasi Belajar Siswa, sebagaimana kajian teori tentang motivasi belajar sebagai berikut :

Motivasi berasal dari bahasa latin"movore", yang berarti menggerakan. Wlodkowski (1985) menjelaskan motivasi merupakan suatu keadaan yang menyebabkan atau menimbulkan perilaku tertentu, dan yang memberi arah serta ketahanan (persistence) pada tingkah laku tersebut. Menurut Imron (1996) menerangkan, bahwa motivasi berasal dari bahasa Inggris motivation, yang artinya dorongan pengalasan dan motivasi. Kata kerjanya adalah to Motive yang artinya mendorong, menyebabkan, dan merangsang. Motive adalah alasan, sebab, dan daya penggerak (Echols, 1984 dalam Imron, 1996).. Motivasi menurut Greenberg adalah proses membangkitkan, mengarahkan, dan memantapkan perilaku arah satu tujuan (Djaali, 2014: 101). Motivasi dan Belajar merupakan dua hal yang saling mempengaruhi. Siswa akan giat belajar jika mempunyai motivasi untuk belajar. Belajar adalah suatu proses usaha yang dilakukan seseorang untuk 
memperoleh perubahan tingkah laku yang baru secara keseluruhan, sebagai hasil pengalamannya sendiri dalam interkasi dengan lingkungan. (Hamdani, $2011: 20$ )

Motivasi Belajar adalah dorongan dalam diri maupun dari luar siswa yang memberikan arah pada kegiatan belajar, untuk mencapai tujuan dari hasil belajar.

Menurut Santrock, Sumber Motivasi secara garis besar terbagi menjadi dua macam, yaitu Motivasi Belajar yang muncul dari luar diri siswa atau sumber Ekstrinsik dan yang muncul dari dalam diri siswa itu sendiri atau Sumber Intern (Kompri, 2016: 232).

1. Sumber Motivasi Ekstrinsik, yaitu melakukan sesuatu untuk mendapatkan sesuatu yang lain (cara untuk mencapai tujuan). Motivasi ekstrinsik sering dipengaruhi oleh insentif eksternal seperti imbalan dan hukuman. Misalnya, murid belajar keras dalam menghadapi ujian untuk mendapatkan nilai yang baik. Terdapat dua kegunaan dari hadiah, yaitu sebagai insentif agar mau mengerjakan tugas, dimana tujuannya adalah mengontrol perilaku siswa, dan mengandung informasi tentang penguasaan keahlian.

2. Sumber Motivasi Instrinsik yaitu motivasi internal untuk melakukan sesuatu demi sesuatu itu sendiri (tujuan itu sendiri). Misalnya, murid belajar menghadapi ujian karena dia senang pada mata pelajaran yang diujikan itu. Murid termotivasi untuk belajar saat mereka diberi pilihan, senang menghadapi tantangan yang sesuai dengan kemampuan mereka, dan mendapat imbalan yang mengandung nilai informasional tetapi bukan dipakai untuk kontrol, misalnya guru memberikan pujian kepada siswa. Terdapat dua jenis motivasi intrinsik, yaitu:

a. Motivasi intrinsik berdasarkan determinasi diri dan pilihan personal. Dalam pandangan ini, murid ingin percaya bahwa mereka melakukan sesuatu karena kemauan sendiri, bukan karena kesuksesan atau imbalan eksternal. Minat intrinsik siswa akan meningkat jika mereka mempunyai pilihan dan peluang untuk mengambil tanggung jawab personal atas pembelajaran mereka. 
b. Motivasi intrinsik berdasarkan pengalaman optimal. Pengalaman optimal kebanyakan terjadi ketika orang merasa mampu dan berkonsentrasi penuh saat melakukan suatu aktivitas serta terlibat dalam tantangan yang mereka anggap tidak terlalu sulit tetapi juga tidak terlalu mudah.

Guru Pendidikan Agama Islam Sekolah Menengah Atas (SMA) Negeri 4 Kota Cirebon dalam hal pembelajaran, memberikan kesempatan kepada siswa untuk lebih aktif, dengan secara berkelompok siswa untuk mempresentasikan bahan ajar. Siswa dalam Pembelajaran Pendidikan Agama Islam Sekolah Menengah Atas (SMA) Negeri 4 Kota Cirebon, ikut berperan aktif, misalnya mempresentasikan hasil diskusi, melakukan tanya jawab dengan teman sekelas dan guru. Guru menguasai materi pembelajaran, tidak bersikap otoriter, dana memberikan motivasi pada saat pembelajaran, disamping itu guru sudah mempersiapkan rencana pembelajaran, seperti bahan ajar, proses pembelajaran dan evaluasi pembelajaran. Ketika menyampaikan materi bahan ajar guru terlihat sudah mengusai materi dan mengkondisikan siswa - siswinya sehingga proses pembelajaran dikelas kondusif.

Permasalahannya adalah Guru Pendidikan Agama Islam Sekolah Menengah Atas (SMA) Negeri 4 Kota Cirebon sudah baik dengan cara melakukan berbagai macam gaya mengajar, akan tetapi masih ada beberapa siswa yang motivasi belajarnya rendah. Mengapa Demikian?

\section{B. Pertanyaan Penelitian}

Berdasarkan pembatasan masalah di atas, maka dapat dirumuskan Pertanyaan penelitian sebagai berikut :

1. Apakah Gaya Mengajar Guru Pendidikan Agama Islam di Kelas XII Sekolah Menengah Atas (SMA) Negeri 4 Kota Cirebon sudah dikategorikan Baik ?

2. Seberapa Besar Motivasi Belajar Kelas XII Siswa Sekolah Menengah Atas (SMA) Negeri 4 Kota Cirebon Mata Pelajaran Pendidikan Agama Islam ?

3. Adakah Pengaruh Gaya Mengajar Guru yang Signifikan Terhadap Motivasi Belajar Mata Pelajaran Pendidikan Agama Islam Siswa Kelas XII Sekolah Mengah Atas (SMA) Negeri 4 Kota Cirebon? 


\section{Tujuan Penelitian}

Penelitian ini bertujuan untuk membuktikan ada tidaknya pengaruh gaya mengajar guru dalam pembelajaran Pendidikan Agama Islam terhadap motivasi belajar siswa. Secara rinci tujuan tersebut meliputi :

1. Memperoleh data tentang Gaya Mengajar Guru Pendidikan Agama Islam di kelas XII Sekolah Mengah Atas (SMA) Negeri 4 Kota Cirebon

2. Memperoleh data tentang Motivasi Belajar Mata Pelajaran Pendidikan Agama Islam Siswa Kelas XII Sekolah Mengah Atas (SMA) Negeri 4 Kota Cirebon

3. Memperoleh data tentang Pengaruh Gaya Mengajar Guru terhadap Motivasi Belajar Mata Pelajaran Pendidikan Agama Islam Siswa Kelas XII Sekolah Mengah Atas (SMA) Negeri 4 Kota Cirebon

\section{Langkah-Langkah Penelitian}

Langkah - langkah yang dilakukan peneliti yaitu : Persiapan dan perencanan, Observasi dan perizinan, Penyusunan Instrumen, Pengumpulan Data, Analisis data dan penyusunan laporan.

\section{PEMBAHASAN}

Penlitian ini dilaksanakan di Sekolah Menengah Atas (SMA) Negeri 4 Kota Cirebon Penelitian telah mendapat persetujuan dari pihak sekolah dan guru Pendidikan Agama Islam Sekolah Menengah Atas (SMA) Negeri 4 Kota Cirebon.

\section{A. Jenis data dan Sumber Data}

\section{Jenis Data}

Jenis penelitian ini bersifat kuantitatif. Penelitian kuantitatif adalah jenis penelitian yang mengahasilkan penemuan-penemuan yang dapat diperoleh dengan menggunakan prosedur-prosedur statistik atau dengan cara-cara dari kualifikasi pengukuran. Penelitian kuantitatif banyak menuntut menggunakan angka, mulai dari pengumpulan data, penafsiran terhadap data tersebut, serta penyajian dari analisis datanya (Suharsimi Arikunto, 2014.10). 


\section{Sumber Data}

a. Sumber data primer, yaitu sumber data utama dari obyek penelitian. Dalam hal ini adalah hasil angket.

b. Sumber data sekunder, yaitu sumber data pendukung yang dapat dijadikan sumber yang bersifat tambahan bagi data utama, seperti wawancara dengan Guru, dan siswa

\section{B. Populasi dan Sampel}

a. Populasi Penelitian

Populasi dalam penelitian adalah siswa kelas XII sebanyak 346 siswa di SMA NEGERI 4 Kota Cirebon tahun ajaran 2016/2017.

b. sampel

teknik pengambilan sampel dalam penelitian ini adalah Simple Random sampling. Dengan pertimbangan teknik analisis angket, dan mendapatkan saran dari guru, serta dikarenakan keterbatasan waktu, tenaga dan materi, maka sampel yang dipilih adalah kelas XII dan diambil enam kelas, yaitu empat kelas XII IPA dan dua kelas XII IPS, atau sama dengan jumlah siswa 177 siswa sebagai sampel, agar sampel lebih representatif dengan taraf kesalahan penelitian $5 \%$

\section{Variabel Penelitian}

Dalam penelitian ini terdiri dari dua variabel, yaitu variabel independen dan variabel dependen.

1. Variabel Independen,

Menurut Sugioyono (2012:61) variabel Independen adalah variabelyang sering disebut sebagai variabel stimulus, predictor, antecedent. Dalam bahasa Indonesia sering disebut sebagai variable bebas.Variable bebas adalah merupakan variable yang mempengaruhi atau yang menjadi sebab perubahanya atau timbulnya variable dependen (terikat). 
Dalam penelitian ini variabel independen (bebas) yaitu Gaya Mengajar sebagai variabel $\mathrm{X}$, untuk menghimpun data pada variabel $\mathrm{X}$ dipergunakan instrument penelitian angket

2. Variabel Dependen

Menurut Sugiyono (2012:61) variabel ini sering disebut sebagai variabel output, kriteria, konsekuen. Dalam bahasa Indonesia sering disebut variabel terikat.Variabel terikat adalah variabel yang dipengaruhi atau yang menjadi akibat, karena adanya variabel bebas.

Dalam penelitian ini variabel dependen (terikat) yaitu Motivasi Belajar sebagai variabel $\mathrm{Y}$, untuk menghimpun data pada variabel Y dipergunakan instrument penelitian angket.

\section{Instrumen Penelitian}

\section{Definisi Konseptual}

Gaya Mengajaradalah suatu cara atau bentuk penampilan yang khas sebagai seorang guru dalam menanamkan pengetahuan, membimbing, mengubah atau mengembangkan kemampuan, perilaku dan kepribadian siswa dalam mencapai tujuan proses belajar

\section{Definisi Operasional}

Gaya Mengajar adalah Skor yang diperoleh Guru dari angket tentang gaya mengajar, dengan indikator ; 1. Gaya Mengajar Klasik, 2. Gaya Mengajar Teknologis, 3. Gaya Mengajar Personalisasi, 4. Gaya Mengajar Interaksi, pada pembelajaran Pendidikan Agama Islam di Sekolah Menengah Atas (SMA) Negeri 4 Kota Cirebon

\section{Kisi - kisi Penelitian}

penelitian ini teknik pengumpulan data yang digunakan sebagai sumber primer adalah angket. Sedangkan yang lain digunakan sebagai sumber pendukung. Menurut sugiyono (2012:199) kuisioner merupakan teknik pengumpulan data yang dilakukan dengan cara memberi seperangkat pernyataan atau pertanyaan tertulis kepada responden untuk dijawabnya. 
Angket yang digunakan dalam penelitian ini menggunakan pernyataan penelitian. Skala yang digunakan adalah skala Likert atau skala sikap dengan alternative lima jawaban, yakni selalu, sering, kadang-kadang, Hampir tidak pernah, tidak pernah.Kisi-kisinya sebagai berikut :

Tabel 1. Kisi - kisi Angket

\begin{tabular}{|c|c|c|}
\hline Variabel Penelitian & Indikator & $\begin{array}{ll}\text { No. } & \text { Item } \\
\text { Instrumen } & \end{array}$ \\
\hline Gaya Mengajar & $\begin{array}{l}\text { 1. } \text { Gaya Mengajar Klasik } \\
\text { 2. Gaya Mengajar Teknologis } \\
\text { 3. Gaya Mengajar Personalisasi } \\
\text { 4. } \text { Gaya Mengajar Interaksional. } \\
\text { Sumber :Sumiati dan Arsa } \\
(2009: 74-76)\end{array}$ & $\begin{array}{l}1,2,3,4,5 \\
6,7,8,9,10 \\
11,12,13,14,15 \\
16,17,18,19,20\end{array}$ \\
\hline $\begin{array}{c}\text { Motivasi Belajar } \\
\text { Siswa }\end{array}$ & $\begin{array}{l}\text { 1. Motivasi Ekstrinsik } \\
\text { 2. Motivasi Instrinsik }\end{array}$ & $\begin{array}{l}1,2,3,4,5,6,7, \\
8,9,10 \\
11,12,13,14,15, \\
16,17,18,19,20\end{array}$ \\
\hline
\end{tabular}

\section{E. Teknik Pengumpulan Data}

Untuk Mengumpulkan berbagai data yang diperlukan, penulis akan menggunakan teknik - teknik sebagai berikut :

a. Studi Dokumentasi

Metode dokumentasi adalah metode yang digunakan untuk menelusuri data historis. Sebagian besar data yang tersedia adalah berbentuk surat-surat, catatan harian, laporan, dan sebaginya. Sifat utama dari data ini tak terbatas pada ruang dan waktu sehingga memberi peluang kepada peneliti untuk halhal yang telah siam (M. Burhan Bungin. 2006 : 166).

Dokumentasi yang akan digunakan pada penelitian ini yaitu pengumpulan data yang bersumber dari tulisan-tulisan, arsip-arsip, atau sumber data yang lainnya yang berhubungan dengan kondisi objek penelitian 
yaitu profil Sekolah Menengah Atas (SMA) Negeri 4 Kota Cirebon yang dijadikan sampel.

b. Angket

Angket dijadikan sebagai teknik pengumpulan data utama, yakni berupa pernyataan tertulis untuk menghimpun sejumlah keterangan dari sumber data tentang gaya mengajar dan motivasi belajar siswa kelas XII Sekolah Menengah Atas (SMA) Negeri 4 Kota Cirebon yang dijadikan sampel penelitian.

Tabel 2. Bobot Skor Skala Likert

\begin{tabular}{|l|c|}
\hline \multicolumn{1}{|c|}{ Alternative jawaban } & Skor \\
\hline Selalu (SL) & 5 \\
\hline Sering (SR) & 4 \\
\hline Kadang-kadang (KK) & 3 \\
\hline Hampir Tidak Pernah (HTP) & 2 \\
\hline Tidak Pernah (TP) & 1 \\
\hline
\end{tabular}

c. Wawancara

Wawancara yaitu pengajuan pertanyaan yang diajukan kepada responden untuk menggali seputar masalah penelitian, baik secara langsung maupun tidak langsung dengan sumber data. Teknik ini digunakan untuk memperoleh data tentang kondisi obyektif di lokasi penelitian dari aparat Kepala Sekolah, Guru dan Staf Tata Usaha Sekolah. (Teknik pengumpulan data hanya ditulis yang betul-betul dipergunakan selama penelitian) di Sekolah Menengah Atas (SMA) Negeri 4 Kota Cirebon

d. Observasi

Metode observasi adalah pengumpulan data yang dilakukan dengan sengaja, sistematis mengenai fenomena sosial dan gejala-gejala lainya untuk kemudian dilakukan pencatatan. Dalam kaitannya dengan penelitian ini penulis langsung terjun ke lapangan menjadi Observasi nonpartisipan, untuk menemukan dan 
mendapatkan data yang berkaitan dengan fokus penelitian, yaitu, Pengaruh Gaya Mengajar Guru dalam Pembelajaran Pendidikan Agama Islam dengan Motivasi Belajar Siswa Sekolah Menengah Atas (SMA) Negeri 4 Kota Cirebon

Obrservasi merupakan salah satu teknik pengumpulan data yang tidak hanya mengukur sikap dari responden (wawancara dan angket) namun juga dapat digunakan untuk merekam berbagai fenomena yang terjadi (situasi, kondisi).Teknik ini digunakan bila penelitian ditujukan untuk mempelajari perilaku manusia, proses kerja, gejala-gejala alam dan dilakukan pada responden yang tidak terlalu besar.

\section{F. Teknik Analisa Data}

\section{Analisis Deskriptif}

Teknik analisis data yang digunakann dalam penelitian ini ialah menganalisis pervariabel dengan menggunakan buku Sugiyono (2016: 246-247), yaitu menghitung skor idel terlebih dulu dan dilakukan secara perindikator. Skor ideal adalah skor yang di tetapkan dengan asumsi bahwa setiap reponden pada setiap pertanyaan memberi jawaban skor tertinggi. Selanjutnya untuk menjawab pertanyaan penelitian nomor 1 dan 2 dapat dilakukan dengan cara membagi jumlah skor hasil penelitian dangan skor ideal.

\section{Uji Korelasi (Product Moment)}

Teknik Analisa Data yang digunakan dalam penelitian ini adalah korelasi product moment dari Person. Analisa korelasi ini digunakan untuk mencari derajat hubungan anatar variabel X (Gaya Mengajar) dengan variabel Y (Motivasi Belajar), dengan menggunakan SPSS :

Langkah - langkah :

1. Analyze

2. Correlate

3. Bivariate

Untuk dapat memberi interprestasi hubungan antara variabel $\mathrm{X}$ dengan variabel Y, digunakan pedoman sebagai berikut : 
Tabel 3. Interpretasi Koefisien Korelasi

\begin{tabular}{|c|c|}
\hline Interval Koefisien & Tingkat Hubungan \\
\hline $0,00-0,99$ & Sangat Rendah \\
$0,20-0,399$ & Rendah \\
$0,40-0,599$ & Sedang \\
$0,60-0,799$ & Kuat \\
$0,80-3,00$ & Sangat Kuat \\
\hline
\end{tabular}

( Sugiyono, $2016: 231$ )

\section{Uji Regresi}

Regresi Linear Sederhana adalah suatu persamaan regresi dimana peubah bebasnya berbentuk skalar. Perhitungan menggunakan SPSS

Langkah - langkah : Klik Anlyze - Regression - Linear

\section{G. Hipotesis Statistik}

Hipotesis Statistik berupa rumus untuk menguji hipotesis. Di sini peneliti akan melakukan penelitian tentang Pengaruh Gaya Mengajar Dalam Pembelajaran Pendidikan Agama Islam Terhadap Motivasi Belajar Siswa Sekolah Menengah Atas (Sma) Negeri 4 Kota Cirebon,Maka Hipotesis Statistiknya adalah sebagai berikut:

Ha : Adanya Pengaruh Gaya Mengajar Guru dalam Pembelajaran Pendidikan Agama Islam Terhadap Motivasi Belajar Siswa Sekolah Menengah Atas (Sma) Negeri 4 Kota Cirebon

Ho : Tidak adaPengaruh Gaya Mengajar Guru dalam Pembelajaran Pendidikan Agama Islam Terhadap Motivasi Belajar Siswa Sekolah Menengah Atas (Sma) Negeri 4 Kota Cirebon. 


\section{PENUTUP}

\section{A. Kesimpulan}

Berdasarkan analisis data dan pembahasan hasil penelitian dapat diperoleh kesimpulan sebagai berikut:

1. Gaya mengajar guru Pendidikan Agama Islam di Sekolah Menengah Atas (SMA) Negeri 4 Kota Cirebon, Berdasarkan hasil perhitungan, maka dapat disimpulkan bahwa gaya mengajar guru PAI di Sekolah Menengah Atas (SMA) Negeri 4 Kota Cirebon lebih dominan menggunakan gaya mengajar teknologis dengan rata - rata $80,18 \%$

2. Motivasi belajar mata pelajaran Pendidikan Agama Islam (PAI) siswa kelas XII Sekolah Menengah Atas (SMA) Negeri 4 Kota Cirebon, Berdasarkan hasil perhitungan, maka dapat disimpulkan bahwa motivasi belajar siswa kelas XII Sekolah Menengah Atas (SMA) Negeri 4 kota Cirebon dalam keadaan baik dengan rata-rata $70,44 \%$.

3. Berdasarkan nilai signifikansi : dari tabel Coefficients di peroleh nilai signifikansi sebesar $0,000<0,05$, sehingga dapat disimpulkan bahwa variabel gaya mengajar guru $(\mathrm{X})$ berpengaruh terhadap variabel motivasi belajar siswa (Y). Adapun pengaruh variabel bebas (gaya mengajar guru) terhadap variabel terikat (motivasi belajar siswa) adalah sebesar 19,8\%.

\section{B. Saran}

Berdasarkan hasil penelitian dan simpulan diatas, penulis mengemukakan beberapa saran sebagai berikut.

1. Bagi guru khususnya guru mata pelajaran PAI hendaknya lebih meningkatkan gaya mengajarnya sehingga siswa akan lebih termotivasi lagi terhadap pembelajaran Pendidikan Agama Islam. Mengikuti pelatihan-pelatihan yang dapat menunjang peningkatan kompetensi guru bisa menjadi salah satu solusi dalam meningkatkan gaya mengajar guru.

2. Bagi siswa diharapkan bisa lebih giat dalam mengikuti pembelajaran Pendidikan Agama Islam karena mata pelajaran ini tidak hanya mengajarkan 
tentang teori tetapi juga mengajarkan hal-hal bisa diterapkan di kehidupan sehari-hari.

3. Karena salah satu faktor yang mempengaruhi Motivasi belajar siswa adalah gaya mengajar guru hendaknya guru disamping berusaha meningkatkan kompetensi yang dimiliki juga memperhatikan kebutuhan siswa agar setiap tujuan pembelajaran yang di harapkan dapat tercapai.

4. Bagi peneliti yang akan meneliti mngenai gaya mengajar guru dan motivasi belajar siswa diharapkan bisa lebih tajam dan luas dalam menganalisis masalah serta lebih memberikan kontribusi yang nyata bagi pihak-pihak yang membutuhkan.

\section{DAFTAR PUSTAKA}

Ahmadi Abu dan Widodo.Psikologi Belajar. Jakarta : Rineka Cipta. Cetakan ketiga. 2013

Ali, Muhammad. Guru Dalam Proses Belajar Mengajar. Bandung: Sinar Baru Algensindo. 2010

Arikunto, Suharsimi. Dasar - dasar Evaluasi.Jakarta : Bumi Aksara. Cetakan Kedua, 2013

Brata Surya. Psikologi Pendidikan. Jakarta : Raja Grafindo Persada. Cetakan ke 18. 2011

Deporter, Bobbi dan Mike Hernacki.Quantum Learning. Cetakan Keenam. Bandung : Kaifa. 2000

Deporter, Bobbi, dkk.Quantum Teaching.Bandung : Kaifa. 2010

Djaali. Psikologi Pendidikan.Jakarta : Bumi Aksara. 2014

Djamarah, Syaiful Bahri dan Aswan. Strategi Belajar Mengajar. Jakarta : Rineka Cipta. Cetakan kelima 2014

Emzir.Metodologi Penelitian Pendidikan kuantitatif dan Kualitatif.Jakarta : Rajawali Pers. 2015

Ghufron, Nur dan Rini Risnawati.Gaya Belajar.Yogyakarta : Pustaka pelajar. Cetakan ketiga. 2014 
Hamalik, Oemar.Psikologi Belajar dan Mengajar.Bandung : Sinar Baru Algensindo. Cetakan kedelapan. 2012

Hamdani.Strategi Belajar Mengjar. Bandung : Pustaka Setia. 2011

Hartanto.Statistik untuk Penelitian.Yogyakarta : Pustaka Pelajar. Cetakan Ke V. 2012

Imron, Ali. Belajar dan Pembelajaran.Jakarta : Dunia Pustaka Jaya. 1996

Kompri.Motivasi Pembelajaran Perspektif Guru dan Siswa. Bandung : Remaja Rosdakarya. 2016

Mardianto.Psikologi Pendidikan. Medan: Perdana Publishing. 2012

Misbahuddin dan Iqbal Hasan.Analisi Data penelitian dengan Statistik.Jakarta Bumi Aksara.Cetakan kedua. 2013

Nurhayati, Eti, Psikologi Pendidikan Inovatif,Yogyakarta : Pustaka pelajar. 2011

Purwanto, Ngalim. Psikologi Pendidikan. Bandung : Remaja Rosdakarya. 2013

Riduan dkk.Cara Mudah Belajar SPSS 17.0 dan Aplikasi Statistik Penelitian.Bandung : Alfabeta. Cetakan Ke tiga. 2013

Sanjaya, Wina. Strategi Pembelajaran. Jakarta : Kencana. Cetakan ke 10. 2013 Sardiman.Interaksi dan Motivasi Belajar Mengajar.Jakarta : Rajawali Press, PT Rajagrafindo Persada. 2015

Soemanto, Wasty. Psikologi Pendidikan. Bandung : Rineka Cipta. 1998

Sugiyono.Metodologi Penelitian Pendidikan. Bandung : Alfabeta. Cetakan ke 24. 2016

Sugiyono.Statistika untuk Penelitian.Bandung : Alfa Beta. Cetakan ke 27. 2016

Sumiati dan Arsa.Metode Pembelajaran. Bandung : Wacana Prima. 2009

Suparman.Gaya Mengajar Yang Menyenangkan Siswa.Yogyakarta : Pinus Book Publisher. 2010

Syah, Muhibin. Psikologi Belajar. Jakarta : Raja Grafindo Persada.cetakan ke 15. 2015

Thoifuri.Menjadi Guru Inisiator. Semarang: Media Campus. . 2008

Thontowi, Ahmad. Psikologi Pendidikan. Bandung : Angkasa. 1991

Wenger, Beyond Teaching \& Learning, Bandung : Nuansa. Cetakan ke 4. 2012

Wlodkowski, Raymond. J dan Judith H. Jaynes.Motivasi Belajar Terjemah

Chairul Annam.Yogyakarta : Cerdas Pustaka. 2004 
